\title{
Experimental Organism Malignant Neuromyoblastoma
}

National Cancer Institute

\section{Source}

National Cancer Institute. Experimental Organism Malignant Neuromyoblastoma. NCI

Thesaurus. Code C116214.

A malignant tumor that arises in the brain stem or adjacent cranial nerves, consisting of variable populations of cells which demonstrate both neuronal and myoblast

differentiation. (INHAND) 